\title{
Examining the horizontal displacement of diaphragm wall embraced by strut affected by piled foundations adjacent to urban deep excavations
}

Examinando el desplazamiento horizontal de la pared del diafragma abrazada por el puntal afectado por cimientos apilados adyacentes a excavaciones profundas urbanas
Author:

Alireza Darvishpour ${ }^{1, *}$

Amirmohammad Amiri ${ }^{2}$

Asadollah Ranjbar ${ }^{3}$

\section{SCIENTIFIC RESEARCH}

How to cite this paper:

Darvishpour. A., Amiri. A., Ranjbar. A. Examining the horizontal displacement of diaphragm wall embraced by strut affected by piled foundations adjacent to urban deep excavations. Robatkarim, Iran. Innovaciencia. 2019; 7 (2): 1-10. DOI:

http://dx.doi.org/10.15649/2346075X.761

Reception date:

Received: 08 February 2019

Accepted: 2 May 2019

Published: 25 October 2019

Keywords:

pile group, numerical modeling, diaphragm wall, urban deep excavation, strut, wall horizontal displacement, wall moment diagram

\begin{abstract}
Utilizing the piled foundation is extremely important and applicable in the civil and geotechnical engineering due to the improvement in the bearing capacity. Employing urban deep excavations, on the other hand, is inevitable and examining the effect of the pile group is significantly vital due to the nearness of adjacent structures. In this research, the effect of the pile group foundation on the diaphragm wall embraced with struts in urban deep excavations is examined using two-dimensional numerical modeling. The results obtained from modeling show that the horizontal distance between the foundation and the excavation edge and also the pile length can significantly affect the horizontal displacement of the wall and the moment diagram imposed on the wall, so that the effect of the foundation on the wall is considerably reduced for the distance greater than a certain value.
\end{abstract}

\footnotetext{
Corresponding author

Department of Civil Engineering, Robatkarim Branch, Islamic Azad University, Robatkarim, Iran. Email: Alireza.darvishpour@gmail.com

2 Department of Civil Engineering, Faculty of Engineering, university of Lorestan, Iran

3 Department of Civil Engineering, East Tehran Branch, Islamic Azad University, Tehran, Iran
} 


\section{INTRODUCTION}

The daily increase in the construction and high density of buildings in urban areas have inevitably led to the use of deep urban excavations to provide the required space. Moreover, exploiting structures on pile group are considerably vital since constructing on weak soils is obligatory. Consequently, examining excavation behaviors affected by the adjacent structures which are constructed on piled foundations is important due to the daily increase in the urban density and nearness of structures.

Several investigations have been performed on the piled foundations placed on soft clay layers ${ }^{[1-3]}$. Moreover, several good three-dimensional pieces of research have been done on the modeling of the piled foundation placed on soft clay layers ${ }^{[4,5]}$.

Generally, the subject of the interaction between foundation, pile, and soil is complex and extremely important and various numerical and analytical methods have been employed about this issue. For instance, Polous ${ }^{[6}$ divided the numerical methods in this field into three categories of 1) simple calculation methods, 2) approximate methods based on computer calculations, and 3) complex approximate methods based on computer calculations.

Several studies have been performed on the behavior of deep urban excavations one of which is the study related to the real recording of the excavation behavior using an electronic measuring tool ${ }^{[7-9]}$. Some experimental investigations in granular and alluvial soils have been performed by Finno et al. and Goh et al. ${ }^{[11]}$ about the interaction between the pile, structure, and the excavation. They showed that the horizontal displacement of the soil can have a considerable effect on the adjacent piles due to the excavation. Of other numerical pieces of research that refer to the excavation effect on the behavior of the moment diagram imposed on the piles and on the horizontal displacement applied to the piles are studies performed by Liyanapathirana and Nishanthan ${ }^{[12]}$ and Lishanthan ${ }^{[13]}$. These researches mainly focus on the horizontal displacement imposed on the pile due to the excavation.

In this research, unlike previous researchers who mainly focused on the effect of excavation on the pile behavior, the interaction between the foundation, pile, and the excavation in urban deep excavations with diaphragm wall and strut is examined using a two-dimensional modeling in finite element program Midas Gts Nx. This research reveals that when the adjacent structure gets further from the excavation edge and also when the pile length are changed the moment and the horizontal displacement imposed on the wall are considerably varied.

\section{NUMERICAL MODELING}

The excavation-foundation-pile system is modeled in two dimensions here in this research using finite element program Midas Gts Nx. Figure (1) shows the two-dimensional modeling conducted in this research. 


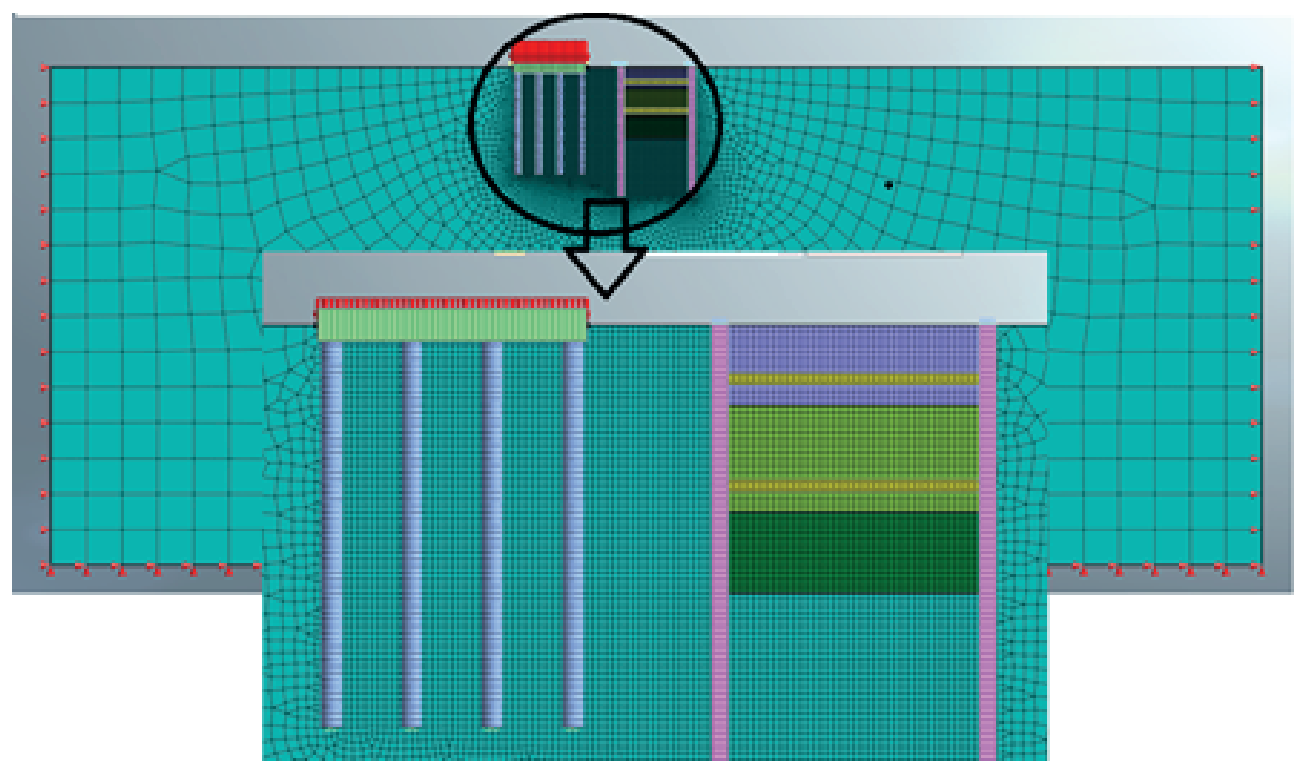

Figure 1: Two-dimensional numerical modeling of the foundation-pile-excavation system

The 4-node two-dimensional plane-strain element is used in the program to numerically model the soil in this research; and the beam element is used to model the pile, retaining wall, foundation, and strut. The interface element available in the program is used to model the behavior between the soil and the structural element the strength reduction factor of which is set to be 0.67 .
The elastoplastic criterion of Mohr-Coulomb is used in this research to model the soil material. In addition, the linear elastic behavior is used to model the structural elements of the foundation, pile, retaining wall, and strut. The material characteristics in this research are presented in table (1).

Table 1: Material characteristics in this research

\begin{tabular}{|c|c|c|c|c|c|}
\hline $\begin{array}{c}\text { Specific weight } \\
\gamma(\mathrm{KN} / \mathrm{m} 3)\end{array}$ & $\begin{array}{c}\text { Cohesion } \\
\mathrm{C}(\mathrm{KN} / \mathrm{m} 2)\end{array}$ & $\begin{array}{c}\text { Internal friction } \\
\text { angle } \emptyset\end{array}$ & $\begin{array}{l}\text { Poisson's } \\
\text { ratio } \mu\end{array}$ & $\begin{array}{c}\text { Elasticity } \\
\text { modulus } \\
\mathrm{E}(\mathrm{kN} / \mathrm{m} 2)\end{array}$ & $\begin{array}{c}\text { Material } \\
\text { name }\end{array}$ \\
\hline 20 & 0.5 & 35 & 0.3 & 70000 & Sand soil \\
\hline 25 & & & 0.2 & $2 \mathrm{e} 7$ & Concrete \\
\hline 78.5 & & & 0.2 & $2 \mathrm{e} 8$ & Steel (strut) \\
\hline
\end{tabular}

The sections used for structural elements in this research are as follow:

1- Strut (the first and second rows): I-shaped section with the height of 39 centimeters, flange width of 30 centimeters, flange thickness of 1.6 centimeters, and web thickness of 1 centimeter

2- Concrete diaphragm wall with the thickness of 60 centimeters

3- Circular pile with the diameter of 80 centimeters

4- Foundation with the thickness of 120 centimeters
The modeling is done in several stages in this research (stage construction) and all the modeling stages are as follow:

The first stage: activating the soil environment, weight load and the support conditions for calculating insitu stresses (the created displacement in this stage are zeroed)

The second step: activating the foundation, pile, and the retaining wall along with their interface elements 
The third stage: activating the load imposed by the structure as a uniform linear load

The fourth stage: deactivating the excavation first layer

The fifth stage: activating the strut in the first row

The sixth stage: deactivating the excavation second layer

The seventh stage: activating the strut in the second row

The eighth stage: deactivating the excavation third layer

\section{THE NUMERICAL MODELING RESULTS}

The results of the modeling are addressed in this section considering the validity of the results obtained from the numerical modeling. Generally, the modeling procedure in this paper is the one mentioned in the second section. Firstly, three different distances are considered in this section between the foundation and the excavation edge which are $0.5,2$, and 5 meters. The foundation width is 10 meters and the center to center distance between the piles is 3 meters and the distance between the marginal piles and the foundation edge is 0.5 meter. The overview of the foundation on the pile considered in this research can be seen in figure (2).

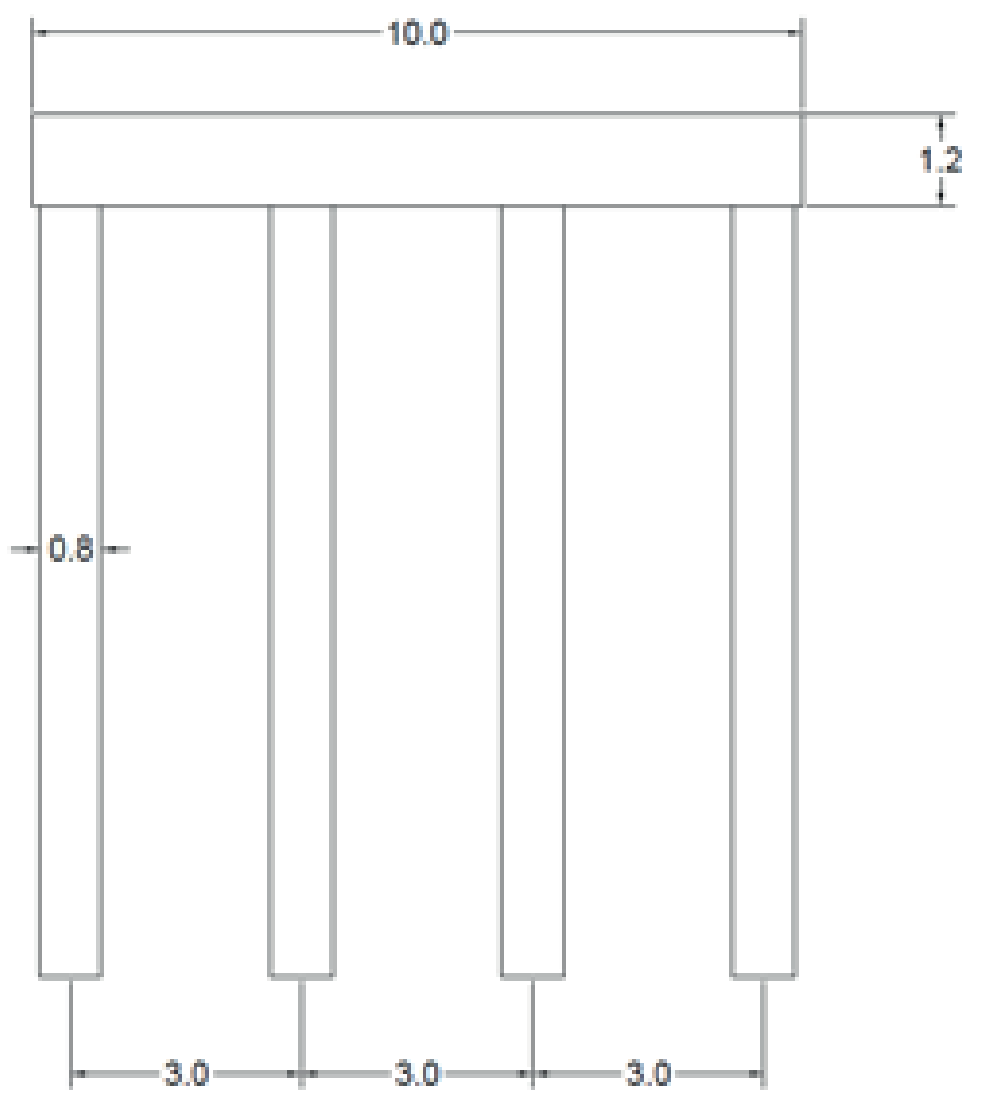

Figure 2: A view of the foundation and piles used in this research

The height of the wall in this study is assumed to be 18 meters, similar to that of the study performed by Chodhury et al. ${ }^{[14]}$, and its width is 0.6 meter and the excavation width is assumed to be 10 meters. The heights of the piles in this study are zero (i.e. no pile), 5, 10, 12, and 15 meters.
The wall horizontal displacements for the case in which there is no pile beneath the foundation and also for the cases in which there are piles with heights of $5,10,12$, and 15 meters at distances of $0.5,2$, and 5 meters from the wall edge are illustrated in figures (3), (4), (5), (6), and (7): 


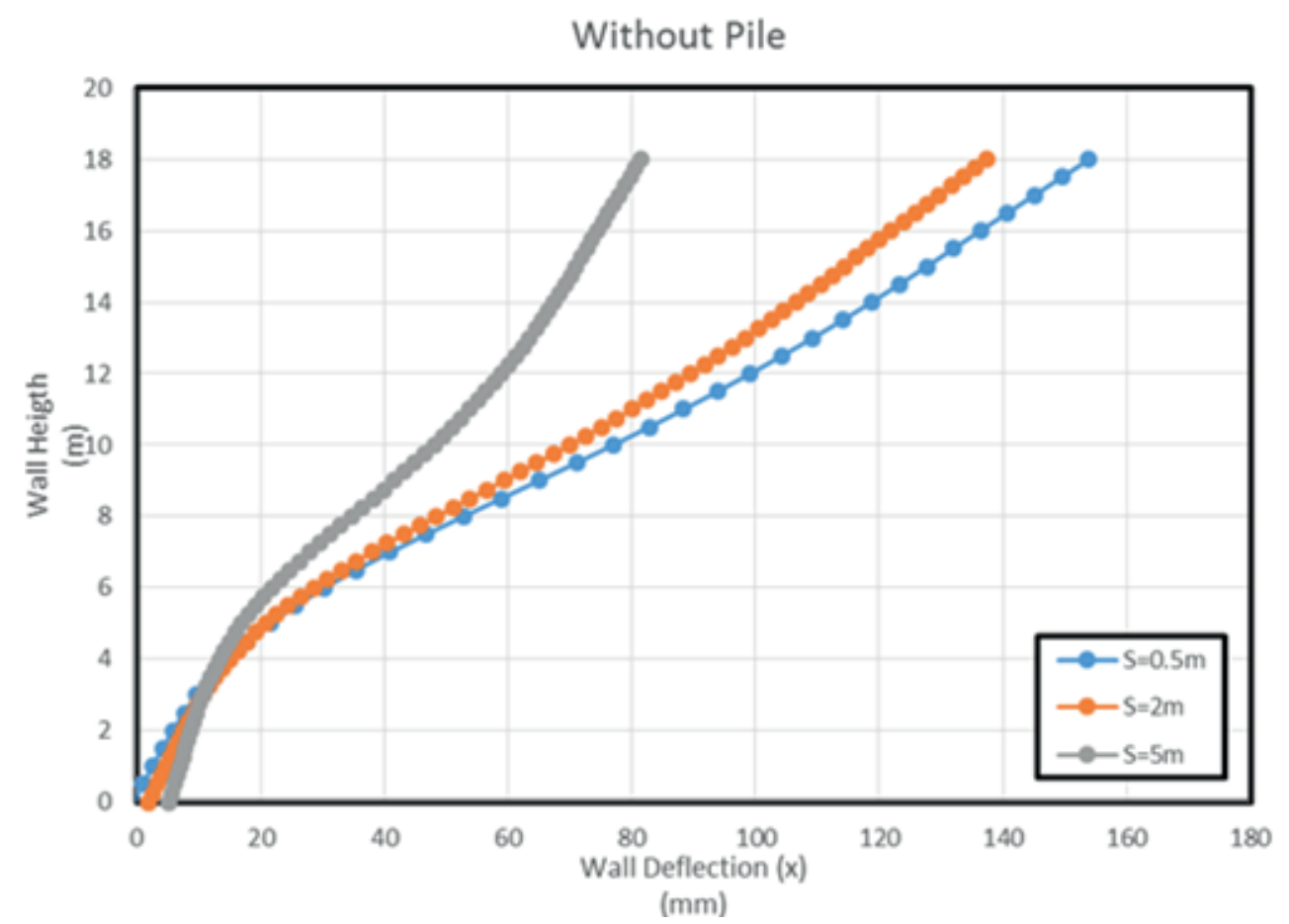

Figure 3: The wall horizontal displacement versus the wall height in case of no pile beneath the foundation Pile ( $L=5 \mathrm{~m})$

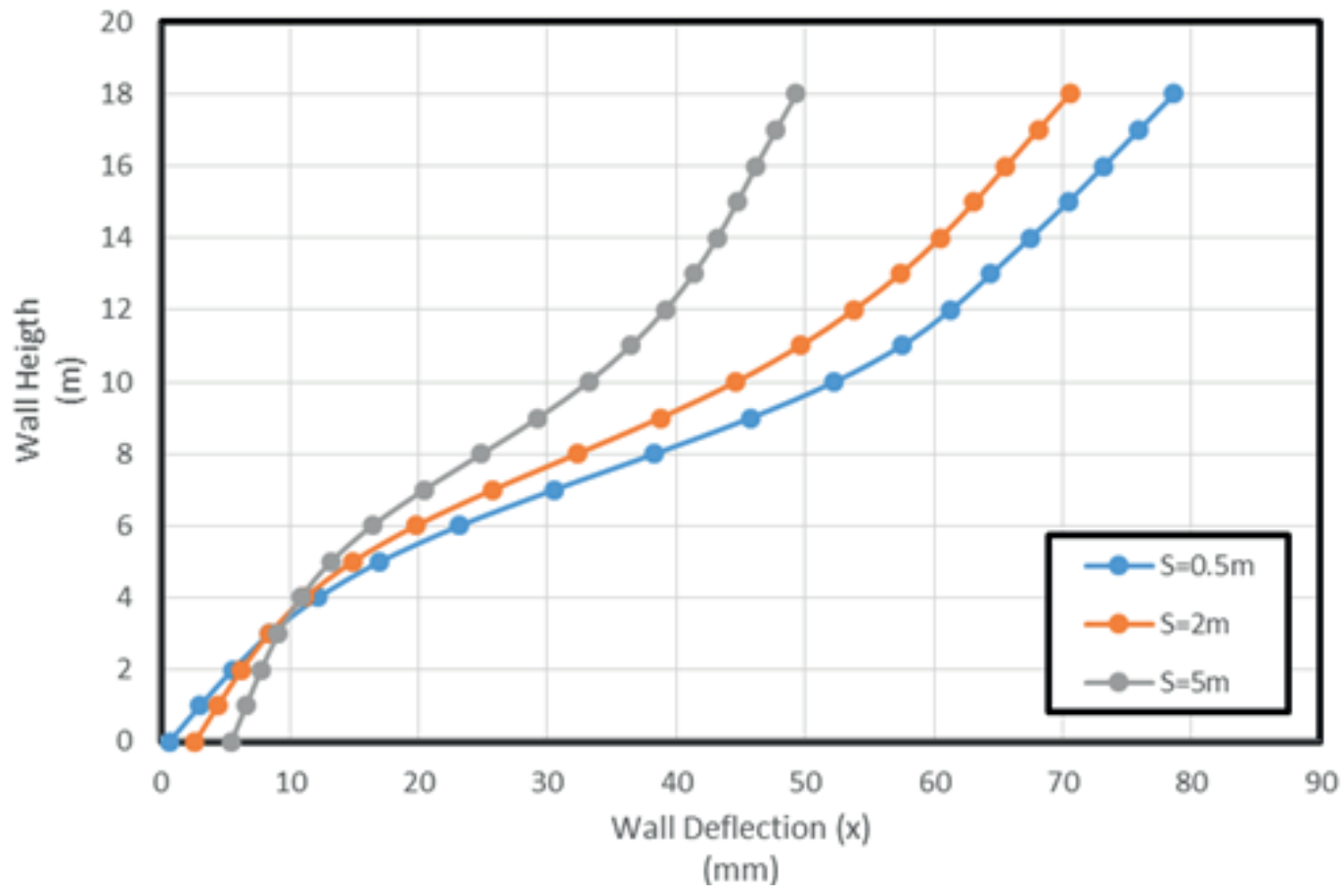

Figure 4: The wall horizontal displacement versus the wall height in case of 5 meters long pile 


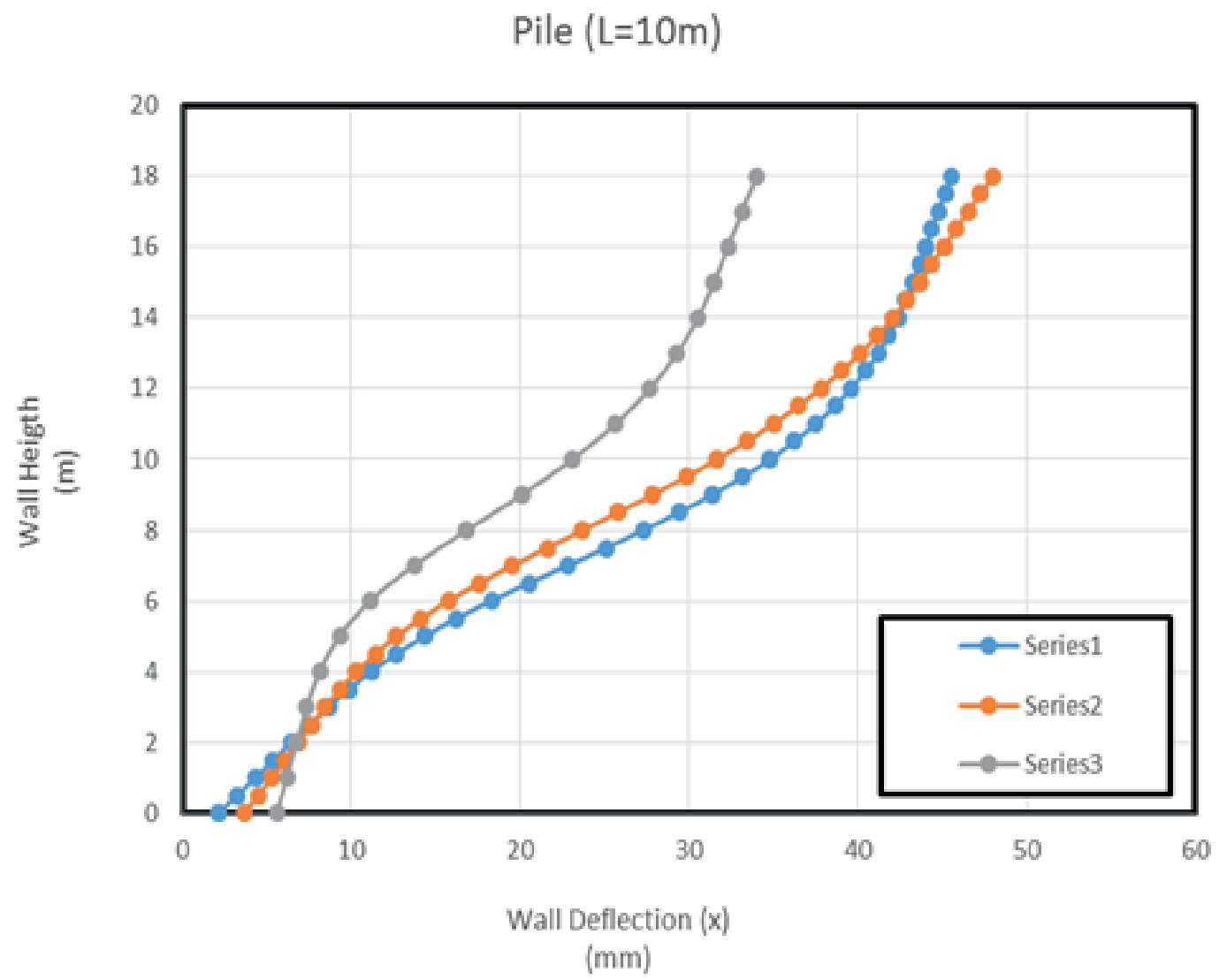

Figure 5: The wall horizontal displacement versus the wall height in case of 10 meters long pile Pile $(\mathrm{L}=12 \mathrm{~m})$

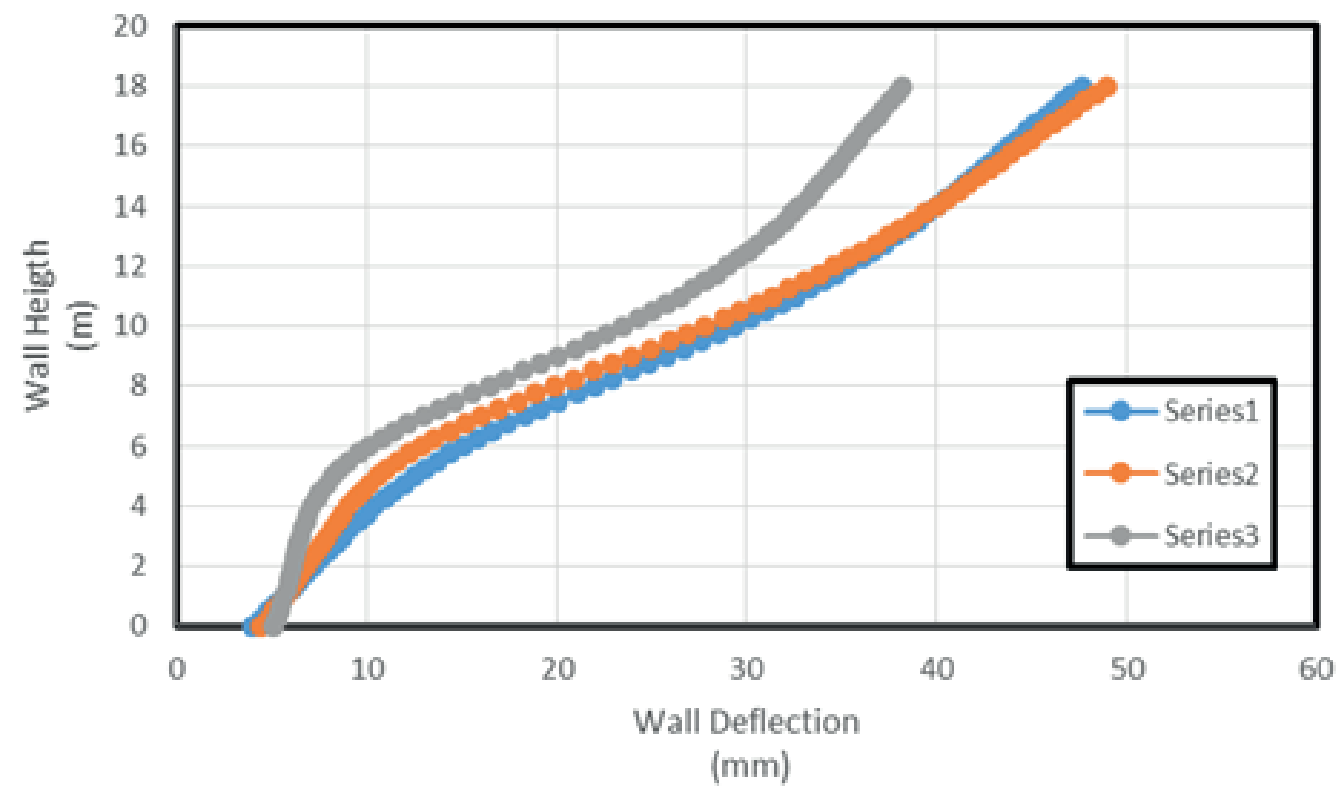

Figure 6: The wall horizontal displacement versus the wall height in case of 12 meters long pile 


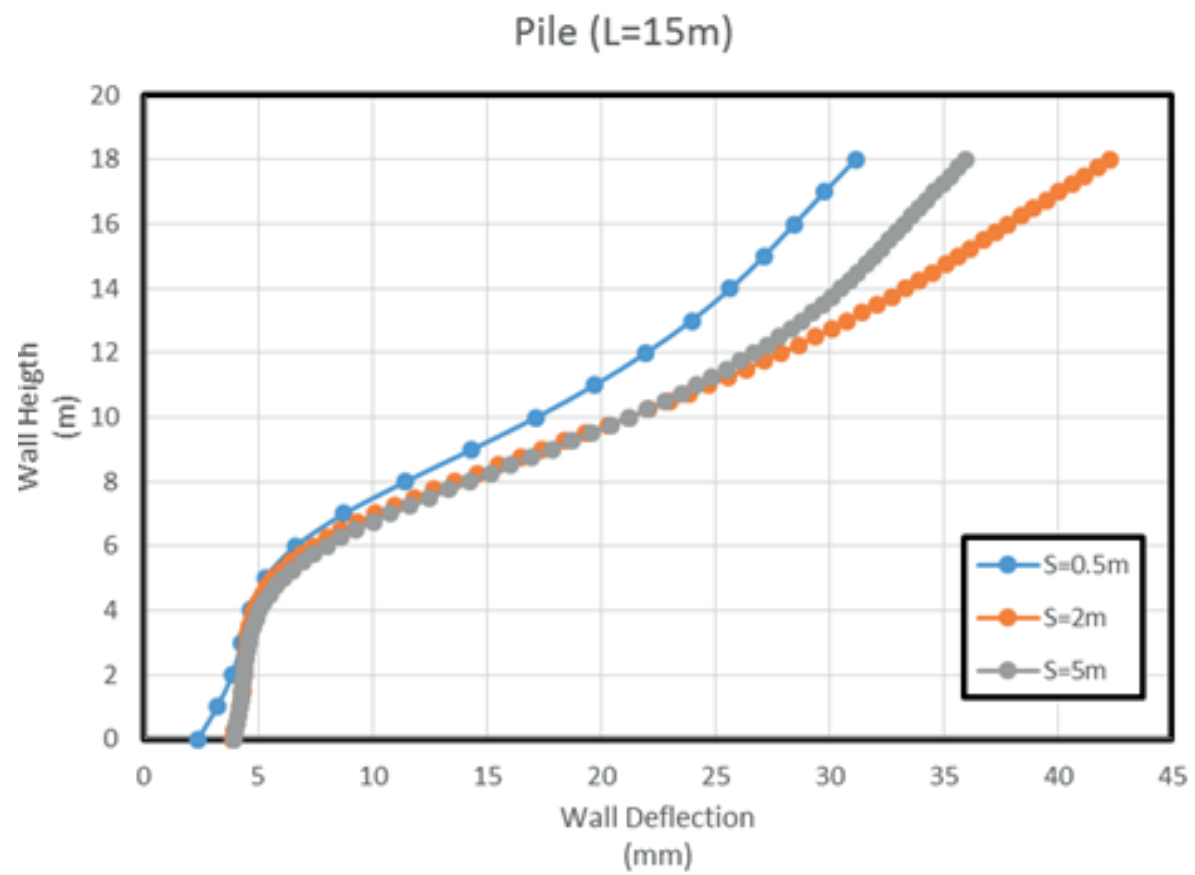

Figure 7: The wall horizontal displacement versus the wall height in case of 15 meters long pile

As can be seen in the above figures, by getting further from the wall the displacement imposed to the wall is reduced. The wall horizontal displacements were almost the same for 0.5 and 2 meters distances from the wall while this displacement is considerably reduced for 5 meters distance from the wall.

The wall displacement for a certain distance and based on the pile heights can be seen in figures (8), (9), and (10). In figure (8), the wall horizontal displacement is shown for 0.5 meter of distance from the wall and for every five cases considered in this research which are no pile and piles with the length of $5,10,12$, and 15 meters. These diagrams are illustrated for the distances of 2 and 5 meters from the wall edge in figures (9) and (10).

$$
\mathrm{S}=0.5 \mathrm{~m}
$$

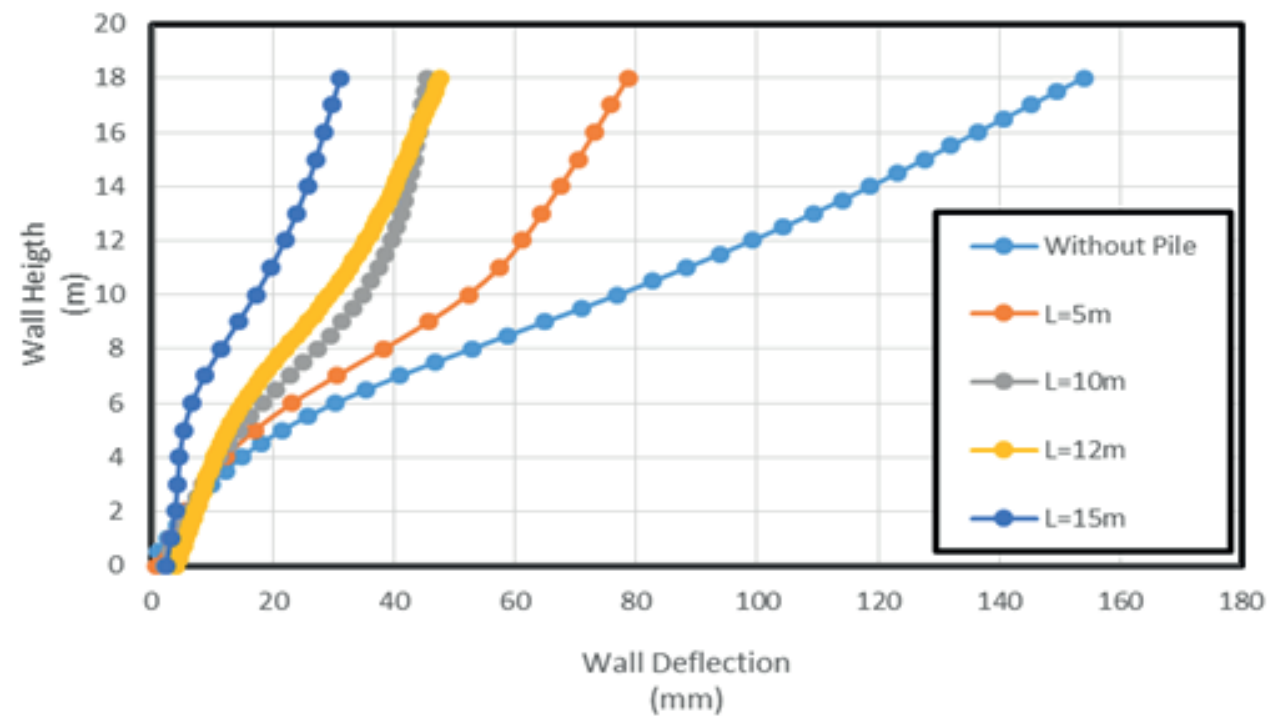

Figure 8: The wall horizontal displacement versus the wall height for the distance of 0.5 meter from the wall edge 


\section{Chart Title}

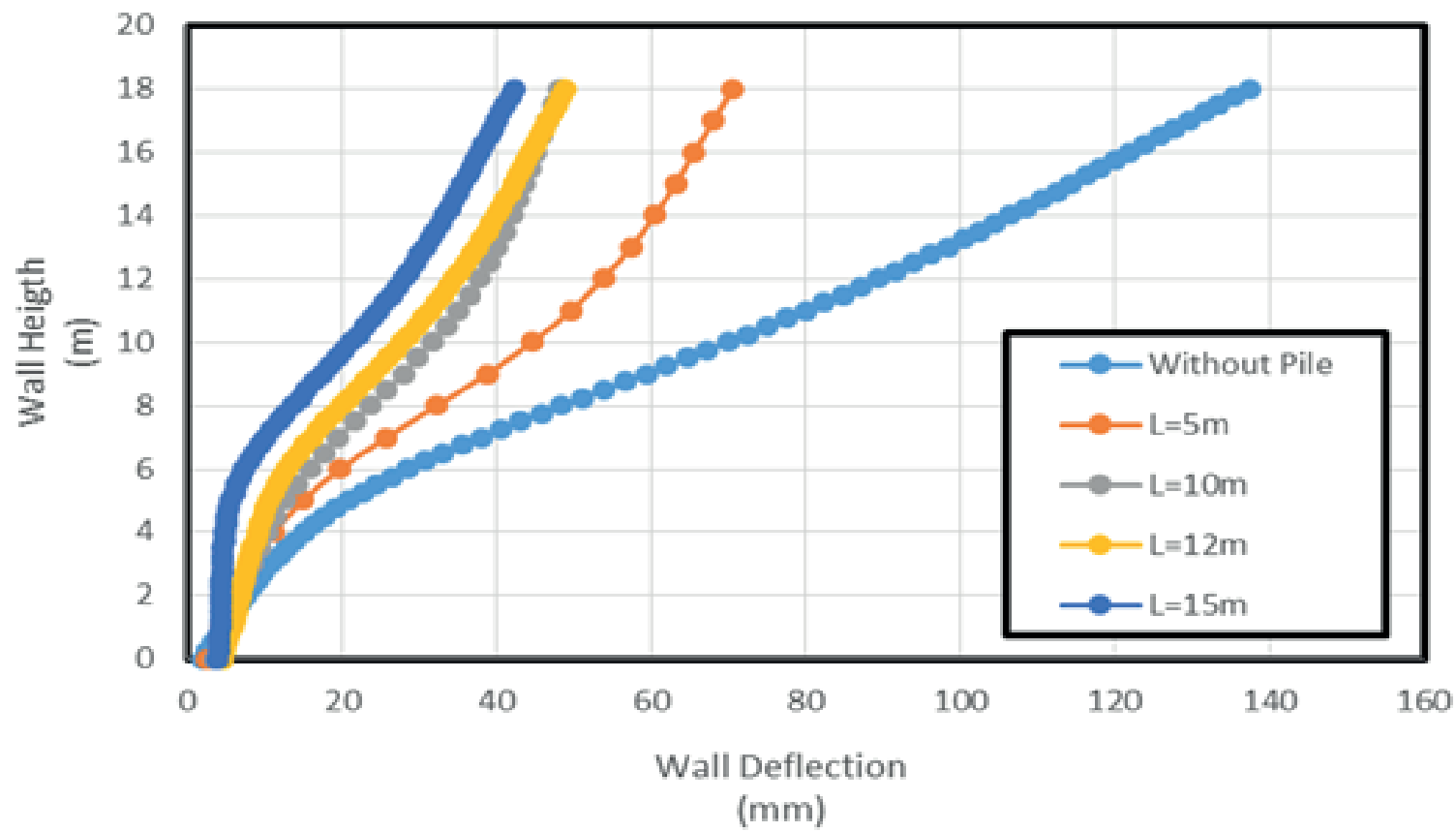

Figure 9: The wall horizontal displacement versus the wall height for the distance of 2 meters from the wall edge

\section{Chart Title}

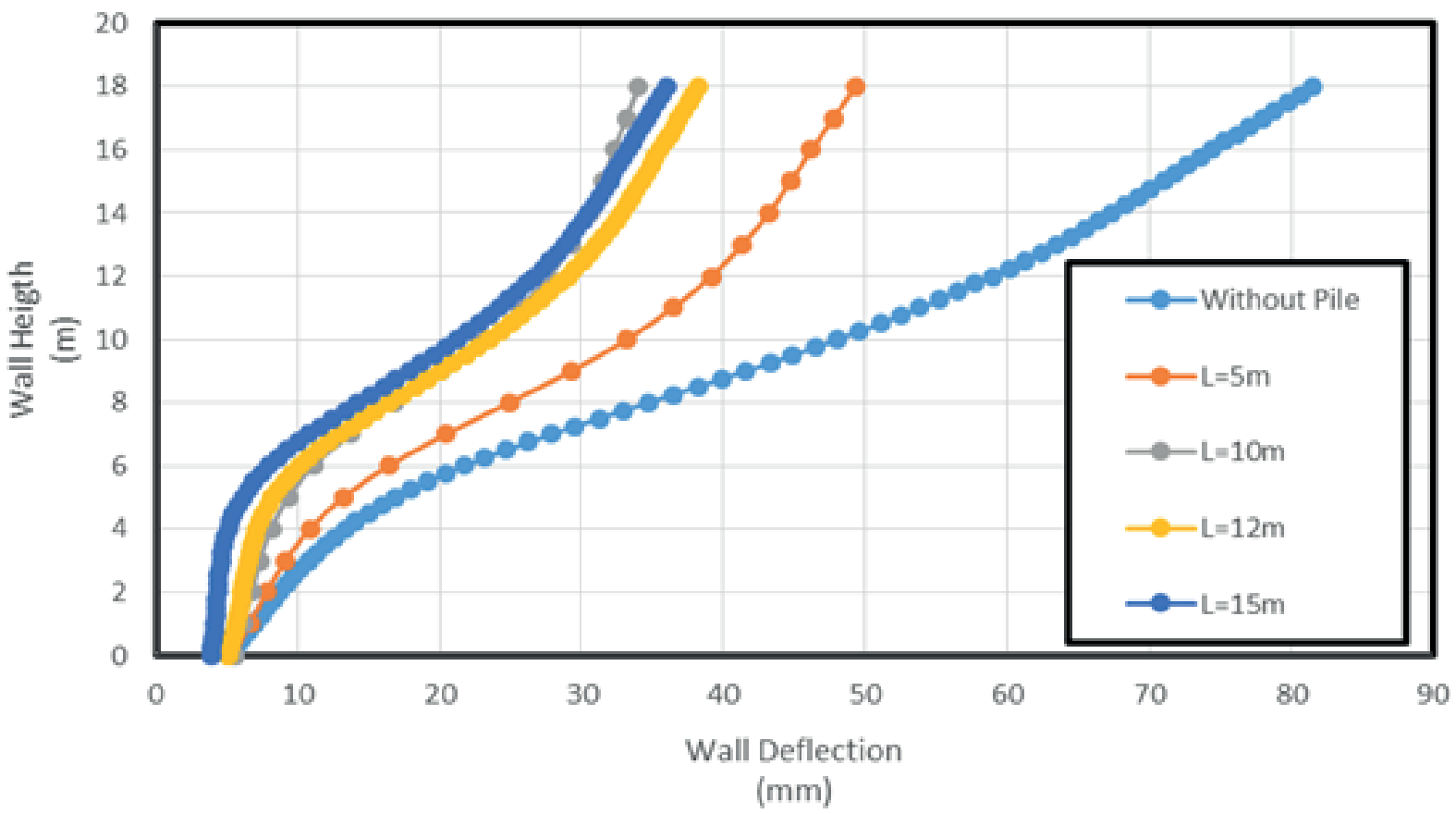

Figure 10: The wall horizontal displacement versus the wall height for the distance of 5 meters from the wall edge 
By assessing the above figures one can realize that the wall horizontal displacement is considerably increased at the top of the wall for the case of no pile because the pressure from the structure is applied towards the ground only through the foundation. But this horizontal displacement of the wall is reduced by adding the piles and also increasing the pile length. As can be seen, the wall displacement imposed by the foundation and pile is not considerably changed when the pile height is more than the wall height.

\section{CONCLUSION}

In this research, the effect of piled foundation on the horizontal displacement of diaphragm wall in urban deep excavation stabilized by wall and strut is examined using finite element program of Midas Gts $\mathrm{Nx}$ in two dimensions. The results of this research can be summarized as:

1- It was observed that the foundation and piles with various length can considerably affect the horizontal displacement imposed on the wall.

2- It is shown in this research that by increasing the foundation distance from the wall edge the wall horizontal displacement will decrease.

3- In case of having no pile the wall horizontal displacement is considerably increased compared to cases with piles because all the pressures are applied by the foundation itself.

4- The applied pressure beneath the foundation is reduced by using piles and also increasing the pile height and the pressure is transferred to the deeper parts of the model. Thus, the wall horizontal displacement is reduced by increasing the wall height.

5- When the pile heights are more than the excavation height then the effects of foundation and pile on the wall horizontal displacement do not change by increasing the pile length.

\section{REFERENCES}

1. Kakurai M, Yamashita K, Tomono M. Settlement behavior of piled raftfoundation on soft ground. In: Proceedings of 8th ARCSMFE; 1987. p. 3736.

2. Poulos HG. Piled raft and compensated piled raft foundations for soft soil sites. Advances on designing and testing deep foundations. Geotech Spec Publ (ASCE) 2005;129:214-35.

https://doi.org/10.1061/40772(170)2

3. Yamashita K, Yamada T, Kakurai M. Simplified method for analyzing piled raft foundations. In: 3rd international geotechnical seminar on deep foundation on bored and auger piles; 1998. p. 457-64.

4. de Sanctis L, Mandolini A. On the ultimate vertical load of piled rafts on the soft clay soils. In: Proceedings of 4th international geotechnical seminar on deep foundation on bored and auger piles. Ghent: Millpress; 2003. p. 379-86.

5. de Sanctis L, Mandolini A. Bearing capacity of piled rafts on soft clay soils. J Geotech Geoenviron Eng (ASCE) 2006;132(12):160010.https://doi.org/10.1061/(ASCE)10900241(2006)132:12(1600)

6. Poulos HG. Methods of analysis of piled raft foundations. A report prepared on behalf of technical committee TC18 on piled foundations. ISSMGE; 2001.

7. Finno RJ, Blackburn JT, Roboski JF. Three-dimensional effects for supported excavations in clay. J Geotech Geoenviron Eng 2007;133(1):306.https://doi.org/10.1061/(ASCE)1090241(2007)133:1(30)

8. Schwamb T, Soga K. Numerical modelling of a deep circular excavation at Abbey Mills in London. Geotechnique 2015;65:604-19.

https://doi.org/10.1680/geot.14.P.251

9. Likitlersuang, S., Surarak, C., Wanatowski, D., Oh, E., \& Balasubramaniam, A. (2013). Finite element analysis of a deep excavation: A case study from the Bangkok MRT. Soils and foundations, 53(5), 756-773.

https://doi.org/10.1016/j.sandf.2013.08.013 
10. Finno RJ, Lawrence SA, Allawh NF, Harahap IS. Analysis of performance of pile groups adjacent to deep excavation. J Geotech Eng 1991;117(6):934-55.

https://doi.org/10.1061/(ASCE)07339410(1991)117:6(934)

11. Goh aTC, Wong KS, Teh CI, Wen D. Pile response adjacent to braced excavation. J Geotech Geoenviron Eng 2003;129(4):383-6.

https://doi.org/10.1061/(ASCE)10900241(2003)129:4(383)

12. Liyanapathirana DS, Nishanthan R. Influence of deep excavation induced ground movements on adjacent piles. Tunn Undergr Sp Technol 2016; 52: 168-81.

https://doi.org/10.1016/j.tust.2015.11.019

13. Nishanthan R, Liyanapathirana DS, Leo CJ. Shielding effect in pile groups adjacent to deep unbraced and braced excavations. Int J Geotech Eng 2016:1-13.

https://doi.org/10.1080/19386362.2016.1200270

14. Chowdhury SS, Deb K, Sengupta A. Estimation of design parameters for braced excavation: numerical study. Int J Geomech 2013;13(3):234-47. https://doi.org/10.1061/(ASCE)GM.1943$\underline{5622.0000207}$ 